\title{
AN ANALYSIS OF PRICE BEHAVIOUR OF RICE IN SRI LANKA AFTER LIBERALIZATION OF ECONOMY
}

\author{
AL Sandika \\ Department of Agricultural Economics and Extension, Faculty of Agriculture, University of Ruhuna, \\ Mapalana, Kamburupitiya, Sri Lanka
}

Accepted: $1^{\text {st }}$ October 2009

\begin{abstract}
Wholesale prices as well as retail prices of rice increased sharply towards the end of 2007 and 2008 . The year 2008/09 rice prices of Samba, Kakulu and $\mathrm{Nadu}$ rice have reached Rs 70, Rs 65 and Rs 50 respectively. Therefore, the objective of this study were to identify the price behaviour of rice in Sri Lanka, to develop the appropriate price forecasting model for rice and to identify the farmers' perception on high rice price in resent past. Year wise nominal market price for Samba, Nadu, and Kakulu rice were collected form different secondary sources. Further, a survey was carried out in Thissamaharama to measure the farmers' perception on high rice prices in the recent past. Forty five farmers were randomly selected to collect the primary data.Year-wise nominal market price (NMP) of all types of rice had increased continuously. However, the real market prices (RMP) of rice have decreased. The Compound Growth Model (CGR) was most appropriate to analyze the price behaviour of Samba and Nadu rice while quadratic model was suitable for Kakulu rice in term of NMP. Further, CGR model was suitable to analyze the price behaviour of Samba while Quadratic model was suitable for Nadu and Kakulu rice in term of RMP. However, $44 \%$ of farmers were satisfied with the high rice price. According to the farmer view, price increment was a result of oligopolistic behaviour of middlemen and insufficient government involvement to control the price.
\end{abstract}

Key words: Nominal market price, Price behaviour, Price forecasting, Real market price

INTRODUCTION

Sri Lanka is a developing country with an area of $65,610 \mathrm{~km}^{2}$ and population of 20.2 million as estimated in 2008, (Central Bank 2008). Agriculture has been the backbone of the Sri Lankan economy with one-thirds of the population being dependent on agriculture. Agricultural sector contributes about $12.1 \%$ of the country's GDP and $32.7 \%$ of the total employment, (Central Bank 2008). Rice is the main crop cultivated by the majority of farmers in rural areas and it is the staple food of the 18.6 million inhabitants in Sri Lanka. Further, it is the livelihood of more than 1.8 million farmers. Rice contributes $1.8 \%$ of country's GDP, (Central Bank 2008). Rice is cultivated in almost all parts of the country, except at very high altitudes as a wetland crop, (Henegedara 2002). Gross extent sown and production in year 2008 were 1,053 thousand hectares and 3,875 thousand metric tons. Paddy production in 2008 year was increased by $23.8 \%$, (Central Bank 2008). Though the domestic production increased yala 2007 and maha 2007/08 season, wholesale prices as well as retail prices of rice increased sharply towards the end of 2007 and 2008. Therefore, cost of living of the consumer is increasing rapidly. The price of rice in end year 2008 have reached Rs 70, Rs 65 and Rs 50 for Samba, Kakulu and $N a d u$, rice respectively. The Government stipulated the maximum retail prices for rice, on $17^{\text {th }}$ of

*Corresponding author: sandika@agecon.ruh.ac.lk

Paper presented at the $2^{\text {nd }}$ National Symposium, Faculty of Agriculture, University of Ruhuna
April 2008 to reduce the cost of living of the consumer. In this sense, forecasting of rice price is very important for all the parties such as consumer, farmers, marketers and policy makers. Therefore, this study attempted to analyses the price behaviour of rice in recent past with following specific objectives,1. to identify the price behaviour of rice in Sri Lanka in resent past after the liberalization of economy, 2. to develop the appropriate price forecasting model for rice and 3. to identify the farmers perception on high rice price in resent past (year 2007 2008).

\section{METHODOLOGY}

Year-wise nominal market price for Samba, Nadu, and Kakulu rice were collected form different secondary sources Central Bank annual reports, report of Department Census and Statistic etc. For Samba and Nadu, time duration was considered as 23 years from 1985 to 2008 . Further, twelve year time duration from 1996 to 2008 was taken for Kakulu rice because limited availability of data. Time Series (TS) plots were used to identify the major price behaviour patterns against the time factor, (Madridakis et al. 1983). Both Nominal Market Price (NMP) and Real Market Price (RMP) were analyzed with the time. Colombo consumer price 
index $(C C P I)(1952=100)$ was used to calculate the RMP, (Hadley 1969). The formula (i) was applied to calculate the RMP.

$\mathrm{RMP}=(\mathrm{NMP} \times 100) / \mathrm{CCPI}$

Correlation between prices of different types of rice was analyzed by using Karl Pearson's product movement correlation coefficient, (Majumdar 2002). The correlation coefficient was defined in the equation (ii). Its value varies from minus one to plus one. If the value is zero there is no relationship between two prices of rice.

$$
\mathrm{r}=\frac{\Sigma \mathrm{XY}-\left(\sum \mathrm{X}\right)\left(\sum \mathrm{Y}\right) / \mathrm{N}}{\sqrt{\left[\sum \mathrm{X}^{2}-\frac{\left.\left(\sum \mathrm{X}\right)^{2}\right]\left[\sum \mathrm{Y}^{2}-\left(\sum \mathrm{Y}\right)^{2}\right]}{\mathrm{N}}\right]}}=\frac{\operatorname{Cov}(\mathrm{X}, \mathrm{Y})}{\mathrm{SD}(\mathrm{X}) \mathrm{SD}} \ldots
$$

Where,

$\mathrm{r}=$ Correlation coefficient, $\mathrm{X}=$ Price of one type of rice $\mathrm{Y}=$ Price of second type of rice and $\mathrm{N}=$ Number of observations

Price behaviour of rice were tested by using different TS models viz; linear $(\mathrm{Y}=\mathrm{a}+\mathrm{bX})$, Quadratic $\left(Y=a+b_{1} X+b_{2} X^{2}\right)$ and Compound Growth Rate (CGR) $\left(Y=a b^{X}\right)$ models with the time factor. CGR was calculated by employing the equation (iii).

$\mathrm{CGR}=(\mathrm{b}-1) 100$

The goodness of fit of model was tested by using coefficients of determination $\left(\mathrm{R}^{2}\right)$, (Majumdar 2002). Coefficients of determination was measured by applying formula (iv)

$\mathrm{R}^{2}=\Sigma\left(\mathrm{y}^{\prime}-\ddot{\mathrm{y}}\right)^{2} / \Sigma(\mathrm{y}-\ddot{\mathrm{y}})^{2}$

Whereas, $\mathrm{Y}=$ production, $\mathrm{y}^{\prime}=$ predicted production and $\ddot{y}=$ mean production

Based on the selected best TS model, appropriate price forecasting model for different types of rice were developed. Further, a survey was carried out to measure the farmers' perception on high rice prices in the recent past. The selected research site was Thissamaharama DS division. Rice farmers were selected as the target population. Primary data was collected from farmers by personal interviews with the help of a structured interview schedule. By considering the land extent of the farmers large (higher than 2.0ha), medium (in between 0.41 to 1.9ha) and small (less than $0.40 \mathrm{ha}$ ) scale rice farmers were randomly selected for the sample survey. Fifteen farmers from each category were selected to form a sample of 45 .

\section{RESULTS AND DISCUSSION}

The nominal price behaviour of different types of rice in the time period is shown in Figure 1. Yearwise prices of all types of rice had increased continuously. Further, two distinct regions could be identified from the TS plot for NMP of rice for the period from 1985 to 2008 . The region 1 could be recognized from 1985 to 2006 with relatively a low gradient. Similarly, region 2 could be identified from 2006 to 2008 with a sharp gradient. Price of all the types of rice have increased with the same pattern. Nevertheless, the RMP of all types of rice have shown decreasing trand (Figure 2). Similar results have been found by Hathurusinghe and Ravichandran (2004), Rupasena et al. (2008) for their study. Hathurusinghe and Ravichandran (2004) analyzed the price of rice in Sri Lanka for the period 1985 to 2002 using percentages, averages and ratios. This analysis showed declining trend in real prices. Further, prices increments of different types of rice have shown a positive correlation. It means that increment of one type of rice price leads to increase the prices of other two types (Table 1). Accordingly the prices of Samba, Nadu and Kakulu rice have increased together.

The $\mathrm{R}^{2}$ of linear regression model, Quadratic model and CRG model were shown Table 2 in term of NMP and RMP. The CGR model was most appropriate to analyze the price behaviour of $S a m b a$ $\left(\mathrm{R}^{2}=97.3 \%\right)$ and $N a d u$ rice $\left(\mathrm{R}^{2}=96.7 .3 \%\right)$ while Quadratic model was suitable for Kakulu rice $\left(\mathrm{R}^{2}=\right.$ $85.4 \%$ ) in terms of NMP. Further, CGR model was most appropriate to analyze the price behaviour of Samba $\left(\mathrm{R}^{2}=95.2 \%\right)$. However, Quadratic model was suitable for Nadu rice $\left(\mathrm{R}^{2}=88.1 \%\right)$ and Kakulu rice $\left(\mathrm{R}^{2}=88.8 \%\right)$ than $\mathrm{CRD}$ model in real terms of price of rice.

The nominal price of Samba rice has increased $7.0 \%$ annually while price of $N a d u$ rice has increased $7.8 \%$ annually from 1985 to 2008 . The price of Kakulu rice has increased by $6.0 \%$ annually. These results are supported by the result observed by Rupasena at el. 2006. He has found the annual compound growth rate of farm price in nom-

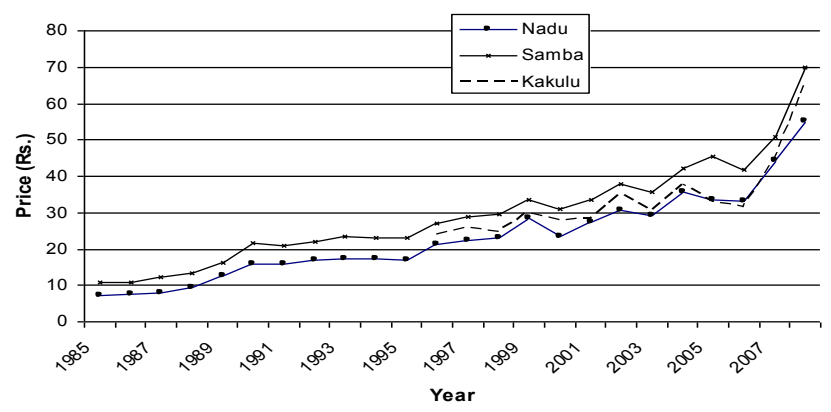

Figure 1: The behaviour of NMP of different types of rice (Sources: Central Bank 1995 - 2008) 


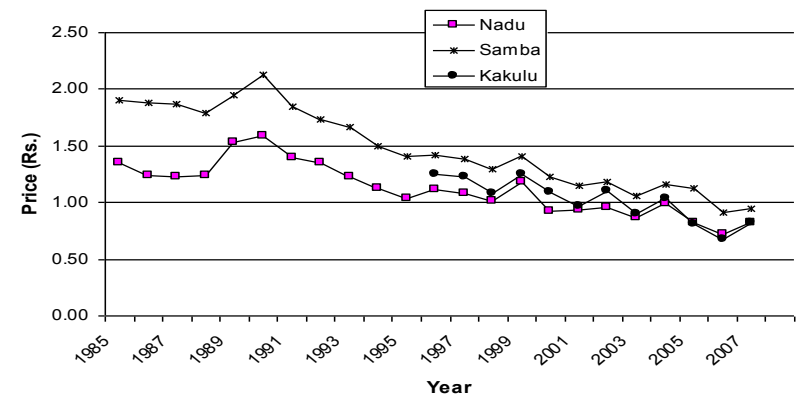

Figure 1: The behaviour of RMP of different types of rice

inal terms was $8.17 \%$ during the pre-liberalized period, 8.27 during post-liberalized period and 9.19 $\%$ for the whole period. Similarly, the increase in retail price registered $10.31 \%$, for the first period, $9.14 \%$ for the second period and $10.36 \%$ for the whole period. With regard to the real prices of Sam$b a, N a d u$ and Kakulu rice have decreased by $4 \%$, $3 \%$ and $5 \%$, respectively per annum. According to Rupasen at el. 2006 the behaviour in real prices have increased by 3.53 and 5.89 percent respectively per annum during the pre-liberalized period as against the negative growth rate of 2.64 percent in farm price and $2.31 \%$ in retail price during the postliberalized period. As a result, real prices either at farm or retail level did not show any significant growth ( $p>0.05$ ) for the period of $1960-2004$. Price forecasting model for both NMP and RMP are shown the Table 3.

Farmers' perceptions on reasons for high retail prices of rice during first quarter of 2008 have shown contradictory results. Around $31.1 \%$ of farmers mentioned that it was a result of oligopolistic behaviour of middlemen while 20.0 percent have mentioned that insufficient government involvement to control the price. In addition, equal percent $(15.6 \%)$ of farmers have indicated that low
Table 1: Correlation matrix of different type of rice

\begin{tabular}{lcc}
\hline & \multicolumn{1}{c}{ Samba } & Kakulu \\
\hline Nadu & $\mathrm{r}=.994(\mathrm{p}=.00)$ & $\mathrm{r}=.969(\mathrm{p}=0.00)$ \\
Samba & & $\mathrm{r}=.967(\mathrm{p}=0.00)$ \\
\hline
\end{tabular}

rice supply from eastern province and reduced rice imports. On the other hand, $44.4 \%$ of farmers have satisfied with high rice prices. Further, $33.3 \%$ of farmers have mentioned that the price has not positively affected the increase the overall profit margin of rice farming since increment of the cost of production at the same time.

\section{CONCLUSIONS}

Year-wise nominal prices of all types of rice had increased continuously. Nevertheless, the real prices of all types of rice have shown decreasing trend. The price of Samba, Nadu and Kakulu rice has increased by $7.0,7.8$ and $6.0 \%$ per annum, respectively. With regard to the real prices of $\mathrm{Samba}, \mathrm{Na}$ $d u$ and Kakulu rice have decreased by $4 \%, 3 \%$ and $5 \%$ respectively per annum. Therefore, farmers' real income has not increased significantly. CGR model was most appropriate model to analyze the price behaviour of Samba and Nadu rice while Quadratic model was suitable for Kakulu rice in term of nominal price. Further, CGR model was suitable to analyze the price behaviour of Samba while Quadratic model was suitable for $N a d u$ and Kakulu rice. According to the farmer, price increment was a result of oligopolistic behaviour of middlemen, insufficient government involvement to control the price. However, $44.4 \%$ of farmers have satisfied about high rice price.

Table 2: Coefficients of determination for different price forecasting models

\begin{tabular}{lcccccc}
\hline \multirow{2}{*}{$\begin{array}{c}\text { Rice } \\
\text { type }\end{array}$} & \multicolumn{2}{c}{$\mathbf{R}^{\mathbf{2}}$ for nominal price (\%) } & \multicolumn{3}{c}{$\mathbf{R}^{2}$ for real price (\%) } \\
\cline { 2 - 7 } & $\begin{array}{c}\text { Linear regres- } \\
\text { sion model }\end{array}$ & $\begin{array}{c}\text { Quadratic } \\
\text { model }\end{array}$ & CGR model & $\begin{array}{c}\text { Linear regres- } \\
\text { sion model }\end{array}$ & $\begin{array}{c}\text { Quadratic } \\
\text { model }\end{array}$ & $\begin{array}{c}\text { CGR mod- } \\
\text { el }\end{array}$ \\
\hline Samba & 93.9 & 95.7 & 97.3 & 94.7 & 94.9 & 95.2 \\
Nadu & 94.4 & 96.0 & 96.8 & 85.5 & 88.1 & 87.1 \\
Kakulu & 77.4 & 85.4 & 83.8 & 88.6 & 88.8 & 87.0 \\
\hline
\end{tabular}

Table 3: Price forecasting model for both NMP and RMP

\begin{tabular}{lll}
\hline \multicolumn{1}{c}{ Rice type } & \multicolumn{1}{c}{ Price forecasting model for NMP } & \multicolumn{1}{c}{ Price forecasting model for RMP } \\
\hline Samba & $\mathrm{Y}^{\mathrm{t}}=1.07^{\mathrm{t}}$ & $\mathrm{Y}^{\mathrm{t}}=6.96 \mathrm{x} 0.96^{\mathrm{t}}$ \\
Nadu & $\mathrm{Y}^{\mathrm{t}}=1.08^{\mathrm{t}}$ & $\mathrm{Y}^{\mathrm{t}}=4.28-0.003 \mathrm{t}^{2}$ \\
Kakulu & $\mathrm{Y}^{\mathrm{t}}=29.9-2.14 \mathrm{t}+0.31 \mathrm{t}^{2}$ & $\mathrm{Y}^{\mathrm{t}}=1.27-0.03 \mathrm{t}+0.001 \mathrm{t}^{2}$ \\
\hline
\end{tabular}




\section{REFERENCES}

Central Bank of Sri Lanka 2008, Central Bank Annual Report 2008, Colombo, Sri Lanka.

Hathurusinghe CP and Ravichandran T 2004 An analyze of the price of rice in Sri Lanka for the period 1985 to 2002, Sri Lanka Journal of Agrarian Studies, Hector Kobbekaduwa Agrarian Research and Training Institute, Colombo, Sri Lanka. $11-1: 63-69$

Hadley G 1969 Elementary Statistics, Holden Day, Inc, Londan, 345- 368.

Henegedara GM 2002 Agricultural Policy reforms in paddy sector in Sri Lanka: An overview. Sri Lankan, Sri Lanka Journal of Agrarian Studies, Hector Kobbekaduwa Agrarian Research and Training Institute, Colombo, Sri Lanka $10-1$ : 26-34
Ljung GM and Box GEP 1978 On a Measure of Lack of Fit in Time Series Model, Biometrika, 65: 6772 .

Madridakis S, Wheelwright SC and McGee VE 1983 Forecasting Methods and Application. Willey, New York.302 pp

Majumdar PK 2002 Statistics A tool for Social Sciences. Rawat Publications, Satyam Apts., Sector 3, Jain Temple Road, Jawahar Napur, Jaipur, India. 319-385

Rupasena L, Kerur NM and Naik AD 2008 Review of Price Behaviour of Rice During Pre and Post -Liberalization Periods, Sri Lanka Journal of Agrarian Studies, Hector Kobbekaduwa Agrarian Research and Training Institute, Colombo, Sri Lanka 12-1: 1-12 